\title{
Are Smartphones Smart for Economic Development?
}

\author{
Rebecca Hartje* \& Michael Hübler ${ }^{\S *}$ \\ Hannover Economic Papers (HEP) No. 555 \\ ISSN 0949-9962 \\ March 2015
}

\begin{abstract}
:
While the worldwide spread of smartphones continues, developing countries have become important markets for these devices. Smartphones' independence of landline networks qualifies them for communication and Internet access in rural areas of developing countries. Drawing upon rural Southeast Asian survey data, this paper provides probably the first empirical evidence for smartphones' contribution to households' income.
\end{abstract}

Keywords: smartphones; mobile phones; technology diffusion; economic development; Southeast Asia

JEL classifications: O18; O33; O53; R20

$\S$ Corresponding author, email: huebler@iuw.uni-hannover.de, phone: +49-511-762-19569, fax: +49-511-762-2667.

* Institute for Environmental Economics and World Trade, Leibniz Universität Hannover, Königsworther Platz 1, 30167 Hanover, Germany.

We acknowledge financial support by the German Research Foundation (DFG) within the project FOR 756. The responsibility for the contents of this discussion paper rests with the authors. Since discussion papers are preliminary, it may be useful to contact the authors about results or caveats. 


\section{Introduction}

The worldwide spread of mobile phones has been an unprecedented technological success story. So far, the literature has identified efficiency gains via mobile phone-based information exchange, for example information about market prices (JENSEN, 2007; TADESSE \& BAHIIGWA, 2014). Meanwhile, the second generation of mobile devices, particularly smartphones, enables mobile access to the information universe and the use of software applications ('apps') with the help of a high-resolution touch-screen. ${ }^{1}$ The independence of landline data networks and electricity grids qualifies them especially for Internet access in remote rural areas of developing countries. Internetbased information about products, prices and economic policy is relevant for business and private use, information about the weather is essential for agriculture, and information about vacant jobs helps job seekers. Compared to regular mobile phones, smartphones extend the possibilities of carrying out financial transactions and offering or purchasing goods or services.

Whether these advantages of smartphones contribute to rural techno-economic development has so far been an open question. The following paper provides a first answer to this question by studying the impact of smartphone ownership on rural households' annual income. Treating smartphone ownership as endogenous, the paper also studies its determinants. It draws upon novel data from rural Southeast Asian ${ }^{2}$ households.

In a narrower sense, the paper contributes to the literature on the determinants and effects of mobile phone use in developing countries, which has so far focused on Africa (BUYS ET AL., 2009; Muto \& YAMANO, 2009; TADESSE \& BAHIIGWA, 2014). In a broader sense, the paper contributes to the literature on ICT (information and communication technologies), digital divide, technology diffusion and economic development (HowARD ET AL., 2009; HEEKS, 2010). To our knowledge, the focus on smartphones is new in this literature.

\footnotetext{
${ }^{1}$ Worldwide quarterly smartphone sales have grown from 36 million to 300 million between 2009 and 2014 (GARTNER STATISTA, 2015). Today half of the earth's adult population owns a smartphone, by 202080 percent of the adult population are expected to own one (THE ECONOMIST, 2015).

2 Thailand, Vietnam, Laos and Cambodia.
} 


\section{Model}

The ultimate goal of our econometric endeavor is to show whether households' smartphone ownership generates an income gain. Smartphone ownership is treated as endogenous, because it likely depends on households' income and other determinants. Therefore, we proceed in two steps. In the first step, we explain smartphone ownership based upon the following cross-sectional probit (treatment or selection) model:

$$
S_{h}=\left\{\begin{array}{c}
1 \text { if } \alpha_{0}+\alpha_{1} \cdot C_{h}+\underline{\alpha}_{2} \cdot \underline{X}_{h}+\varepsilon_{1 h}>0 \\
0 \text { otherwise }
\end{array}\right.
$$

The index $h$ denotes households. $S_{h}$ is a binary variable depicting a household's smartphone ownership in the form: 'no smartphone' implies $S_{h}=0$, 'at least one smartphone' implies $S_{h}=1$. A higher annual consumption value, indicated by $C_{h}$ and measured in per capita form, is expected to increase the likelihood of smartphone ownership. $C_{h}$ addresses the endogeneity of smartphone ownership with respect to households' wealth. $\underline{X}_{h}$ represents a column-vector of control variables which explain smartphone ownership. First, we model rural technology diffusion via spatial correlation in form of the unweighted mean of smartphone ownership $\left(0 \leq S_{h}{ }^{m} \leq 1\right)$ within political administrative districts. Second, we include the average household age. Whereas young people tend to generate low income, they tend to show technological affinity. Third, we include the highest number of years spent at school by any household member in order to capture income effects and education-related technological knowledge. Furthermore, we assume that households' standard occupation is subsistence farming and control for the number of household members engaged in off-farm employment or in self-employment. The type of occupation can have an income effect and affect the usefulness of possessing a smartphone. Fourth, we capture country-specific effects in the form of binary variables. ${ }^{3}$ To complete the first-step equation, we define $\alpha_{0}$ as the overall constant, $\alpha_{1}$ as the coefficient of income, and $\underline{\alpha}_{2}$ as a row-vector that contains the coefficients for each control variable. All $\alpha$-parameters are to be estimated. $\varepsilon 1 h$ is the error term of the first step.

\footnotetext{
${ }^{3}$ We will use province-specific effects in the second step. Using province-specific effects in the first step, too, would create collinearity across the two steps.
} 
In the second step, we explain the impact of smartphone ownership on households' income based upon the following linear, cross-sectional (outcome) model:

$$
\log I_{h}=\beta_{0}+\beta_{1} \cdot S_{h}+\underline{\beta}_{2} \cdot \underline{Y}_{h}+\varepsilon_{2 h}
$$

Ih signifies a household's annual income value per capita which enters the equation in naturallogarithmic form. $S_{h}$ is the binary smartphone variable introduced above. $\underline{Y}_{h}$ represents a columnvector of control variables. First, within the category of social factors, the household size ${ }^{4}$ may influence income. We add the education measure as introduced in the first step, because we expect that better education enhances income. Furthermore, we take affiliation to an ethnic majority into account in order to capture possible social or political privileges. Second, households' total value of tangible assets may raise income. Third, available technologies, represented by access to the electricity grid, may complement or substitute smartphones. We add a binary variable for the ownership of mobile phones (including smartphones) in the form: 'no mobile phone' represented by 'zero', 'at least one mobile phone' represented by 'one'. This allows us to identify the advantages of smartphones in addition to mobile phones. Fourth, we capture province-specific effects as binary variables. The $\beta$-parameters are to be estimated. $\varepsilon 2 h$ is the error term of the second step.

\section{Data}

We use novel data which were collected in household surveys in the rural Southeast Asian Mekong region at the beginning of the year 2013. Besides data from Thailand and Vietnam (HARDEWEG ET AL., 2012), our data include Laos and Cambodia as novel research areas. ${ }^{5}$ We include all four countries in our regressions and leave out one country at a time in a robustness check (Supplement E). The data cover over 5000 households living in about 500 villages which were selected via threestage stratified random sampling. In the data from Vietnam and Laos, poorer households are

\footnotetext{
${ }^{4}$ Wide definition that includes the core family plus anybody living with and belonging to the core family according to the respondents.

${ }^{5}$ The data cover eight provinces: Buriram, Nakhon Phanom and Ubon Ratchathani in Thailand; Dak Lak, Ha Tinh and Thua Thien Hue in Vietnam; Savannakhet in Laos; and Stung Treng in Cambodia.
} 
overrepresented. We correct for this via sampling weights. Pecuniary variables are measured in 2005-PPP $-\$$.

The survey data report mobile phone ownership as well as the age and the value of the most recently bought mobile phones. This information allows us to determine whether a mobile phone belongs to the category of advanced mobile devices, so-called smartphones. We use the average price for smartphones fabricated in China including tariffs and taxes, equivalent to 2014-US-\$159, as the standard threshold price, above which a new mobile phone is deemed to be a smartphone. We explore a lower threshold price of 2014-US-\$50 and an upper price of 2014-US-\$253 as well (for details see Supplement C).

The data show that smartphone ownership covers all survey regions and the sample's whole income distribution except very low incomes. The share of smartphone owners among all households based on the standard definition is three percent, whereas it is 17 percent based on the lower bound definition and one percent based on the upper bound definition (Supplement A). In comparison, 87 percent of all households own a regular mobile phone (including smartphones). With respect to the standard definition, smartphone owners receive an average annual income of 2005-PPP-\$4463, whereas non-smartphone owners receive 2005-PPP-\$-2248. ${ }^{7}$

\section{Estimation}

When implementing Equations (1) and (2), we check that the correlations between regressors are sufficiently low (Supplement B). We find that the criteria for applying treatment effects estimators based on propensity scores are not unambiguously fulfilled. (For details and a robustness check on the choice of the estimator see Supplement D). Hence, we estimate Equations (1) and (2) simultaneously as a linear endogenous treatment regression (ETR) by means of the maximum likelihood (ML) criterion. A Wald-test clearly rejects the null-hypothesis that all estimated parameter values (except the constant) are equal to zero. We obtain the average treatment effect (ATE) of smartphone ownership with respect to households' annual income (given by the

\footnotetext{
${ }^{6}$ Purchasing power parity.

${ }^{7}$ The difference is significant with $p \approx 0$ according to a $t$-test.
} 
coefficient of the smartphone variable) in step two as well as factors that affect the probability of smartphone ownership in step one. We start by estimating the two equations separately via Ordinary Least Squares (OLS) and ML. We then proceed with ETRs.

\section{Results}

Table 1 reports the estimated parameter values with heteroscedasticity-robust $p$-values in parentheses and the corresponding significance levels indicated by stars. In columns (1) and (2) we apply the standard definition of smartphones, in column (4) the lower and in column (5) the higher price definition. In column (3) we model mobile phone instead of smartphone ownership as an endogenous variable for comparison.

Table 1 about here.

The income effect of smartphone ownership is positive in all columns and statistically and economically highly significant. Whereas the income effect of mobile phone ownership is much lower than that of smartphone ownership as long as mobile phones are treated as an exogenous variable, it strongly increases when mobile phones are modeled endogenously in column (3). Meanwhile, the income effect of smartphones declines in column (3) but stays highly significant.

In both steps, the coefficients of the control variables have the expected signs and are in most cases statistically highly significant. Yet, according to the outcome regression results, access to the electricity grid is no significant determinant of households' income. Household size reduces smartphone ownership, which points to increasing dependency and poverty in larger households. According to the treatment regressions results, self-employment and off-farm employment increase the probability of smartphone ownership. This indicates that the occupation matters for smartphone ownership. Notably, we find highly significant spatial correlation of smartphone ownership within districts. 
Our results are qualitatively robust with respect to several robustness checks using different definitions of smartphones, a double-robust treatment effects estimator, a reduced number of countries, and introducing threshold income dummies (Table 1 and Supplements C, D, E and F).

\section{Conclusion}

Drawing upon survey data from rural Southeast Asian households, we find a significant and positive impact of smartphone and mobile phone ownership on households' income. This impact is qualitatively robust across several robustness checks. We conclude that advanced mobile communication devices can support rural techno-economic development. Hence, development assistance may foster the infrastructure for the spread of such devices.

Our paper has pointed to a new research avenue. Future surveys may distinguish different types of advanced mobile devices, such as smartphones, tablets and notebooks, which are not yet common in developing countries today.

\section{References}

BuYs, P., S. Dasgupta \& T.S. ThOMAs (2009). Determinants of a Digital Divide in Sub-Saharan Africa: A Spatial Econometric Analysis of Cell Phone Coverage. World Development 37(9), 1494 1505.

GARTNER STATISTA (2015). Global Smartphone Sales to End Users from 1st Quarter 2009 to 3rd Quarter 2014. Access (01/2015): http://www.statista.com/statistics/266219/global-smartphonesales-since-1st-quarter-2009-by-operating-system/.

Hardeweg, B., S. Klasen \& H. Waibel (2012). Establishing a Database for Vulnerability Assessment. In: Klasen, S. and H. Waibel (eds.), Vulnerability to Poverty: Theory, Measurement and Determinants, with Case Studies from Thailand and Vietnam, 50-79, Palgrave Macmillan, Hampshire, UK.

HeEks, R. (2010). Do Information and Communication Technologies (ICTs) Contribute to Development? Journal of International Development 22, 625-640.

HowARD, P.N. \& N. MAZAHERI (2009). Telecommunications Reform, Internet Use and Mobile Phone Adoption in the Developing World. World Development 37(7), 1159-1169. 
Jensen, R. (2007). The Digital Provide: Information (Technology), Market Performance, and Welfare in the South Indian Fisheries Sector. Quarterly Journal of Economics 122(3), 879-924.

Muto, M. \& T. Yamano (2009). The Impact of Mobile Phone Coverage Expansion on Market Participation: Panel Data Evidence from Uganda. World Development 37(12), 1887-1896.

TAdesse \& BAhilgwa (2014). Mobile Phones and Farmers' Marketing Decisions in Ethiopia. World Development 68, 296-307.

The ECONOMist (2015). Planet of the Phones: The Smartphone is Ubiquitous, Addictive and Transformative. The Economist 414(8927), February $28^{\text {th }}, 9$. 


\section{Supplementary online appendix}

\section{Supplement A: Descriptive summary statistics}

The following table describes our novel data which were collected in household surveys in the rural Southeast Asian Mekong region at the beginning of the year 2013. They cover the countries Thailand, Vietnam, Laos and Cambodia. Because the income data contain negative values generated by depreciation or losses, we add the lowest negative value to all income values in the sample before taking logs.

Table Supplement A about here.

Supplement B: Correlations between variables

The following matrix depicts the correlations between the variables in the form, in which they enter the regressions.

Table Supplement B about here.

Supplement C: Definition of the smartphone variables

Our survey data for the year 2013 contain information on a household's, $h$, most recently obtained mobile phone, purchased during the years, $t \in\{2010,2011,2012,2013\}$ and its purchase price, $p h t$ (i.e. the value according to the respondents). Households reside within one of the countries, $c \in$ \{Thailand, Vietnam, Laos, Cambodia\}. For each country and year, we calculate a threshold price, above which mobile phones are treated as smartphones:

$$
\tilde{p}_{c t}=\bar{p} \cdot \epsilon_{c t} \cdot \delta_{c t} \cdot\left(1+\tau_{c t}\right) \cdot(1+\theta)^{2014-t}
$$


We express $\tilde{p}_{c t}$ in $2005-\mathrm{PPP}^{8}-\$$ in order to relate it to our survey data which are measured in the same unit. $\bar{p}$ denotes a given threshold price measured in 2014-US-\$. According to GFK (2014), the average price for a smartphone manufactured in China and sold under a Chinese brand in 2014 was 2014-US-\$159, which we use as the standard threshold price, $\bar{p}$, for our analysis. As a robustness check, we consider a lower and an upper bound for $\bar{p}$ as well. We choose the lowest selling price for a Chinese-brand smartphone, 2014-US-\$50, as the lower bound and the average price for a Western-brand smartphone, 2014-US-\$253, as the upper bound (all numbers according to GFK, 2014). $\epsilon_{c t}$ symbolizes a PPP-based exchanged rate and $\delta_{c t}$ a country-specific CPI ${ }^{9}$-based deflator, which we calculate with CPI data published by the WORLD BANK (2015). $\tau_{c t}$ is an advalorem rate that captures local taxes and import tariffs. We use tax rates from the WORLD BANK (2015) and tariff rates from WTO (2015). $\theta$ represents the rate of technical progress in the fabrication of smartphones, reflected by annual price reductions for smartphones. We follow DESILVER (2013) who suggests a rate of $\theta=0.0835$.

Let us introduce an auxiliary variable that denotes a specific smartphone, $S_{h t}$, owned by household $h$ in $t$, with a corresponding specific purchase price, $p h t^{\prime}$. We can now posit that a household $h$, residing in country $c$, owns 'at least one smartphone' so that the binary variable $S_{h}$ used in our regressions becomes $S_{h}=1$ if $\sum_{t} S_{h t}{ }^{\prime}>0$ where $S_{h t}{ }^{\prime}=1$ if $p_{h t}{ }^{\prime} \geq \tilde{p}_{c t}$. Otherwise, the household owns 'no smartphone' so that $S_{h}=0$.

\section{Supplement D: Choice of the estimator and robustness}

We consider the application of treatment effects estimators based on propensity scores. Such estimators require the validity of three criteria (ROSENBAUM AND RUBIN, 1983; cf. WOOLDRIDGE, 2010, section 21): (1) conditional independence (or unconfoundedness) between the treatment model and the potential outcomes, (2) overlap between the treatment and control group, (3) independent and identically distributed individuals (stable unit treatment value). Since a Wald-test, performed after a maximum likelihood estimation of the linear endogenous treatment regression (ETR) in most cases rejects the null hypothesis of independent first- and second-step unobservables, criterion (1) is violated. Regarding criterion (2), we can achieve a sufficient overlap

${ }^{8}$ Purchasing power parity.

${ }^{9}$ Consumer price index. 
between the treatment and control group (see below). Nonetheless, the treatment group is very small compared with the control group. The validity of criterion (3) is questionable, too, because we deal with rural technology diffusion. This implies that smartphone ownership of one individual is supposed to encourage smartphone ownership of other individuals and may affect their income (i.e., the outcome variable) via information exchange.

As a consequence, we prefer estimating Equations (1) and (2) as an ETR model, also known as endogenous binary-variable model, based on Heckman $(1976,1978)$. The maximum likelihood estimator version that we utilize has been introduced by Maddala (1983). This model type does not require the strict fulfillment of the criteria discussed above. We limit the number of explanatory variables that appear in both equations to mitigate collinearity between the equations (cf. PUHANI, 2000).

Notwithstanding, we estimate Equations (1) and (2) via a treatment effects estimators based on propensity scores as a robustness check. We choose the inverse-probability-weighted regression adjustment estimator (IPWRA), because it is double-robust ${ }^{10}$ and allows for a detailed specification of the outcome model according to Equation (2) (cf. WoOLDRIDGE, 2010, section 21.3.4). To ensure sufficient overlap, we eliminate observations whose propensity score is below the maximum of the minima of the treatment (smartphone owners) and control group (non-smartphone owners). Likewise, we eliminate observations whose propensity score is above the minimum of the maxima (cf. CALIENDO \& Kopeining, 2008).

The estimated average treatment effects (ATEs) of smartphone ownership corroborate the significantly positive impact on households' annual per capita income. Yet, there are two differences to the previous results. First, the magnitudes of the ATEs drop to between 0.035 and 0.065. Second, the statistical significance of the treatment vanishes for the low threshold price definition of smartphones. The detailed results are available upon request.

\footnotetext{
${ }^{10}$ It requires only the outcome model or the treatment model to be correctly specified.
} 


\section{Supplement E: Three- and one-country robustness check}

In this robustness check, we estimate Equations (1) and (2) with the default definition of smartphones via ETR and leave out one of the four countries in each estimation.

The following table shows the results. Accordingly, our previous results hold in general when removing one country. Yet, when removing Thai households from the sample, the statistical significance of the ATE vanishes $(p=0.11)$. One explanation is the drastic decrease in the number of observations by 1987. Another explanation is that smartphone ownership plays the most important role in Thailand among the countries in the sample. This accords with the highest gross domestic product per capita of Thailand among the sample countries.

Table Supplement E about here.

In order to better understand the role of specific countries in the sample, we include only one of the four countries at a time in each regression in another robustness check. It turns out that despite the substantially reduced number of observations, smartphones (according to the standard definition) entail an economically and statistically highly significant positive effect on income for Thailand, Vietnam and Cambodia, but not for Laos. The detailed results are available upon request.

\section{Supplement F: Threshold income robustness check}

In this robustness check, we estimate Equations (1) and (2) with the default definition of smartphones via ETR with the full sample of four countries. We check the following aspect: Smartphone ownership may reflect affluence, and this affluence may not be sufficiently captured by the first-step regression based on Equation (1). To address a possible smartphone-affluence nexus explicitly, we introduce three different threshold income dummy variables in the secondstep Equation (2): First, the mean income of all households in the sample ('mean income' in the following table); second, the mean income plus one standard deviation ('mean + std dev income'); third, the mean income of all smartphone owners in the sample based on the standard definition of 
smartphones ('mean sphone income'). We attributed the value 'one' to all households with incomes above the corresponding threshold and a 'zero' to the remaining households.

The following table shows the results. Accordingly, our previous results hold in general when controlling for threshold income levels. Yet, the magnitude of the income effect of smartphone ownership declines to a level below that in the OLS estimation reported by column (1) in Table 1. This indicates that the results reported by Table 1 may encompass income-related as well as non-income-related aspects of smartphone (and mobile phone) ownership.

Table Supplement $\mathrm{F}$ about here.

References for the supplementary online appendix

Caliendo, M. \& S. Kopeining (2008). Some Practical Guidance for the Implementation of Propensity Score Matching. Journal of Economics Surveys 22(1), 31-72.

Desilver, D. (2013). The Falling Price of a Smartphone. PewResearchCenter, Washington, DC, USA, access (12/2014): http://www.pewresearch.org/fact-tank/2013/09/10/the-average-sellingprice-of-a-smartphone/.

GFK (2014). Smartphone Sales in Seven Key Southeast Asia Markets Reached More than USD 16.4 billion in Past 12 Months. Gesellschaft für Konsumforschung, Nürnberg, Germany, access (12/2014): http://www.gfk.com/sg/news-and-events/press-room/press-releases/pages/smartphonesales-in-seven-key-southeast-asia-markets-reached-more-than-usd-16-4-billion-in-past-12months-gfk.aspx.

Heckman, J. (1976). The Common Structure of Statistical Models of Truncation, Sample Selection and Limited Dependent Variables and a Simple Estimator for Such Models. Annals of Economic and Social Measurement 5, 475-492.

Heckman, J. (1978). Dummy Endogenous Variables in a Simultaneous Equation System. Econometrica 46, 931-959.

MaddalA, G.S. (1983). Limited-Dependent and Qualitative Variables in Econometrics. Cambridge University Press, USA.

Puhani, P.A. (2000). The Heckman Correction for Sample Selection and its Critique. Journal of Economic Surveys 14(1), 53-68.

RosenBAum, P.R., \& D.B. RUBIN (1983). The central role of the propensity score in observational studies for causal effects. Biometrika 70, 41-55. 
Wooldridge, J.M. (2010). Econometric Analysis of Cross Section and Panel Data. $2^{\text {nd }}$ edition, The MIT Press, Cambridge, MA, USA and London, UK.

WORLD BANK (2015). World Development Indicators (WDI). The World Bank Group, Washington, DC, USA, access (02/2015): http://data.worldbank.org/data-catalog/worlddevelopment-indicators.

WTO (2015). Consolidated Tariff Schedules (CTS) database. World Trade Organization, Geneva, Switzerland, access (02/2015): http://tariffdata.wto.org/. 


\begin{tabular}{|c|c|c|c|c|c|c|c|c|c|c|}
\hline \multirow{2}{*}{$\begin{array}{l}\text { Column number } \\
\text { Estimation method } \\
\text { Dependent variable }\end{array}$} & \multicolumn{2}{|c|}{1} & \multicolumn{2}{|c|}{$\begin{array}{c}2 \\
\text { ETR }\end{array}$} & \multicolumn{2}{|c|}{$\begin{array}{c}3 \\
\text { ETR }\end{array}$} & \multicolumn{2}{|c|}{$\begin{array}{c}4 \\
\text { ETR }\end{array}$} & \multicolumn{2}{|c|}{$\begin{array}{c}5 \\
\text { ETR }\end{array}$} \\
\hline & $\begin{array}{l}\text { Separate } \\
\text { linear } \\
\text { log Inc pc }\end{array}$ & $\begin{array}{l}\text { gressions } \\
\text { probit } \\
\text { SPhone std }\end{array}$ & $\begin{array}{l}\text { Outcome } \\
\text { linear } \\
\text { log Inc pc }\end{array}$ & $\begin{array}{l}\text { Treatment } \\
\text { probit } \\
\text { SPhone std }\end{array}$ & $\begin{array}{l}\text { Outcome } \\
\text { linear } \\
\text { log Inc pc }\end{array}$ & $\begin{array}{c}\text { Treatment } \\
\text { probit } \\
\text { MPhone } \\
\end{array}$ & $\begin{array}{l}\text { Outcome } \\
\text { linear } \\
\text { log Inc pc }\end{array}$ & $\begin{array}{l}\text { Treatment } \\
\text { probit } \\
\text { SPhone low }\end{array}$ & $\begin{array}{l}\text { Outcome } \\
\text { linear } \\
\text { log Inc pc }\end{array}$ & $\begin{array}{l}\text { Treatment } \\
\text { probit } \\
\text { SPhone high }\end{array}$ \\
\hline Household size & $\begin{array}{c}-0.024^{* * * *} \\
(0)\end{array}$ & & $\begin{array}{c}-0.024^{* * * *} \\
(0)\end{array}$ & & $\begin{array}{c}-0.028^{\star \star \star *} \\
(0)\end{array}$ & & $\begin{array}{c}-0.025^{\star * * *} \\
(0)\end{array}$ & & $\begin{array}{c}-0.024^{\star * * *} \\
(0)\end{array}$ & \\
\hline Education & $\begin{array}{c}0.0082^{* * * *} \\
(2.8 \mathrm{e}-06)\end{array}$ & & $\begin{array}{c}0.0080^{* * * *} \\
(3.0 \mathrm{e}-06)\end{array}$ & & $\begin{array}{l}0.0050^{* * * *} \\
(0.00047)\end{array}$ & & $\begin{array}{c}0.0073^{* * * *} \\
(4.0 \mathrm{e}-06)\end{array}$ & & $\begin{array}{c}0.0081^{* * * *} \\
(2.7 \mathrm{e}-06)\end{array}$ & \\
\hline Tangible assets & $\begin{array}{c}3.2 \mathrm{e}-06^{* * * *} \\
(0.0017)\end{array}$ & & $\begin{array}{c}3.1 \mathrm{e}-06^{* * * *} \\
(0.0019)\end{array}$ & & $\begin{array}{c}3.2 \mathrm{e}-06^{* * * *} \\
(0.0012)\end{array}$ & & $\begin{array}{c}2.9 \mathrm{e}-06^{* * * *} \\
(0.0034)\end{array}$ & & $\begin{array}{c}3.3 e-06^{* * * *} \\
(0.0010)\end{array}$ & \\
\hline Electricity grid & $\begin{array}{l}0.018 \\
(0.39)\end{array}$ & & $\begin{array}{l}0.016 \\
(0.44)\end{array}$ & & $\begin{array}{c}0.0023 \\
(0.91)\end{array}$ & & $\begin{array}{l}0.016 \\
(0.43)\end{array}$ & & $\begin{array}{l}0.020 \\
(0.34)\end{array}$ & \\
\hline Mobile phone & $\begin{array}{c}0.066^{* * * *} \\
(0.000028)\end{array}$ & & $\begin{array}{c}0.066^{* * * *} \\
(0.000031)\end{array}$ & & $\begin{array}{c}0.52^{* * * *} \\
(0)\end{array}$ & & $\begin{array}{c}0.054^{\star * * *} \\
(0.00089)\end{array}$ & & $\begin{array}{c}0.068^{* * * *} \\
(0.000014)\end{array}$ & \\
\hline Mobile phone district & & & & & & $\begin{array}{c}2.51^{* * * *} \\
(4.1 \mathrm{e}-08)\end{array}$ & & & & \\
\hline Smartphone standard & $\begin{array}{c}0.16^{\star * \star *} \\
(0.00100)\end{array}$ & & $\begin{array}{c}0.25^{\star * \star *} \\
(0.000014)\end{array}$ & & $\begin{array}{l}0.15^{\star \star \star *} \\
(0.0036)\end{array}$ & & & & & \\
\hline Smartphone distr std & & $\begin{array}{c}6.31^{* * * *} \\
(0)\end{array}$ & & $\begin{array}{c}8.01^{* * * *} \\
(0)\end{array}$ & & & & & & \\
\hline Smartphone low price & & & & & & & $\begin{array}{c}0.26^{* * *} \\
(0.0068)\end{array}$ & & & \\
\hline Smartphone distr low & & & & & & & & $\begin{array}{c}3.00^{\star \star \star *} \\
(1.4 \mathrm{e}-07)\end{array}$ & & \\
\hline Smartphone high price & & & & & & & & & $\begin{array}{c}0.28^{* * * *} \\
(0.00033)\end{array}$ & \\
\hline Smartphone distr high & & & & & & & & & & $\begin{array}{c}18.9^{* * * *} \\
(0)\end{array}$ \\
\hline Consumption per capita & & $\begin{array}{c}0.000092^{* * * *} \\
(9.7 \mathrm{e}-06)\end{array}$ & & $\begin{array}{c}0.00010^{* * * *} \\
(4.3 e-06)\end{array}$ & & $\begin{array}{c}0.00025^{\star * * *} \\
(4.8 \mathrm{e}-06)\end{array}$ & & $\begin{array}{c}0.00011^{* * * *} \\
(2.1 \mathrm{e}-06)\end{array}$ & & $\begin{array}{c}0.000072^{\star * * *} \\
(0.00050)\end{array}$ \\
\hline Average age & & $\begin{array}{c}-0.0062 \\
(0.15)\end{array}$ & & $\begin{array}{c}-0.0094^{* *} \\
(0.044)\end{array}$ & & $\begin{array}{c}-0.016^{* * * *} \\
(0)\end{array}$ & & $\begin{array}{c}-0.014^{\star * \star *} \\
(4.2 \mathrm{e}-06)\end{array}$ & & $\begin{array}{c}-0.0074 \\
(0.22)\end{array}$ \\
\hline Education & & $\begin{array}{c}0.018^{* * * *} \\
(0.000035)\end{array}$ & & $\begin{array}{l}0.013^{* * * *} \\
(0.0018)\end{array}$ & & $\begin{array}{c}0.038^{* * * *} \\
(0.0025)\end{array}$ & & $\begin{array}{c}0.0075 \\
(0.13)\end{array}$ & & $\begin{array}{l}0.014^{* * * *} \\
(0.00066)\end{array}$ \\
\hline Off-farm employment & & $\begin{array}{l}0.075^{* *} \\
(0.015)\end{array}$ & & $\begin{array}{l}0.086^{* *} \\
(0.015)\end{array}$ & & $\begin{array}{l}0.079^{* * * *} \\
(0.0022)\end{array}$ & & $\begin{array}{l}0.072^{* *} \\
(0.030)\end{array}$ & & $\begin{array}{l}0.094^{* *} \\
(0.036)\end{array}$ \\
\hline Self-employment & & $\begin{array}{c}0.13^{* *} \\
(0.027)\end{array}$ & & $\begin{array}{c}0.15^{* *} \\
(0.014)\end{array}$ & & $\begin{array}{c}0.50^{* * * *} \\
(0)\end{array}$ & & $\begin{array}{c}0.18^{* * * *} \\
(0.00063)\end{array}$ & & $\begin{array}{l}0.098 \\
(0.28)\end{array}$ \\
\hline Country dummies $^{\circ}$ & no & yes & no & yes & no & yes & no & yes & no & yes \\
\hline Number of observations & 5,157 & 5,170 & 5,157 & 5,157 & 5,157 & 5,157 & 5,157 & 5,157 & 5,157 & 5,157 \\
\hline
\end{tabular}


Supplement A: Descriptive statistics.

\begin{tabular}{|c|c|c|c|c|c|}
\hline Variables & Unit & Mean & Std dev & Min & Max \\
\hline Sample size & \# of observations & 5170.00 & & & \\
\hline Household size & \# of people & 5.05 & 2.07 & 1 & 23 \\
\hline Off-farm employment & \# of people & 1.24 & 1.25 & 0 & 8 \\
\hline Self-employment & \# of people & 0.34 & 0.66 & 0 & 6 \\
\hline Average age & \# of years & 33.98 & 11.96 & 10 & 90 \\
\hline Education & \# of years & 9.18 & 4.57 & 0 & 33 \\
\hline Tangible assets & 2005-PPP-\$ & 5043.75 & 9959.88 & 0 & 146142 \\
\hline Consumption per capita & 2005-PPP-\$ / (\# of people) & 2022.66 & 1735.18 & 121 & 30668 \\
\hline Income per capita & 2005-PPP-\$ / (\# of people) & 2304.16 & 3365.16 & -4468 & 52183 \\
\hline Ethnic majority & binary & 0.77 & 0.42 & 0 & 1 \\
\hline Electricity grid & binary & 0.84 & 0.37 & 0 & 1 \\
\hline Mobile phone & binary & 0.87 & 0.33 & 0 & 1 \\
\hline Smartphone low & binary & 0.17 & 0.37 & 0 & 1 \\
\hline Smartphone standard & binary & 0.03 & 0.16 & 0 & 1 \\
\hline Smartphone high & binary & 0.01 & 0.11 & 0 & 1 \\
\hline
\end{tabular}


Supplement B: Correlations between variables.

\begin{tabular}{|c|c|c|c|c|c|c|c|c|c|c|c|c|}
\hline Variables & $\log \operatorname{lnc} \mathrm{pc}$ & HSize & Educ & Assets & Majority & Electric & MPhone & SPhone & Cons pc & Age & Off-farm & Self-empl \\
\hline log Income per capita & 1.00 & & & & & & & & & & & \\
\hline Household size & -0.10 & 1.00 & & & & & & & & & & \\
\hline Education & 0.12 & 0.11 & 1.00 & & & & & & & & & \\
\hline Tangible assets & 0.13 & 0.07 & 0.16 & 1.00 & & & & & & & & \\
\hline Ethnic majority & 0.14 & -0.09 & 0.18 & 0.10 & 1.00 & & & & & & & \\
\hline Electricity grid & 0.00 & -0.09 & 0.27 & 0.10 & 0.14 & 1.00 & & & & & & \\
\hline Mobile phone & 0.09 & 0.09 & 0.27 & 0.14 & 0.18 & 0.26 & 1.00 & & & & & \\
\hline Smartphone standard & 0.09 & 0.04 & 0.07 & 0.15 & 0.01 & 0.00 & 0.06 & 1.00 & & & & \\
\hline Consumption per capita & 0.37 & -0.17 & 0.14 & 0.30 & 0.13 & 0.01 & 0.12 & 0.19 & 1.00 & & & \\
\hline Average age & 0.06 & -0.42 & 0.04 & 0.00 & 0.12 & 0.24 & -0.04 & -0.02 & 0.08 & 1.00 & & \\
\hline Off-farm employment & 0.10 & 0.34 & 0.24 & -0.01 & 0.09 & 0.11 & 0.13 & 0.03 & -0.01 & -0.09 & 1.00 & \\
\hline Self-employment & 0.25 & 0.06 & 0.11 & 0.21 & 0.13 & 0.07 & 0.12 & 0.05 & 0.18 & -0.02 & -0.09 & 1.00 \\
\hline
\end{tabular}


Supplement E: Income effects (log annual per capita value) of smartphone ownership (binary), 3 of 4: Thailand, Vietnam, Laos, Cambodia.

\begin{tabular}{|c|c|c|c|c|c|c|c|c|}
\hline $\begin{array}{l}\text { Column number } \\
\text { Countries included } \\
\text { Estimation method }\end{array}$ & Vietnam, L & $\begin{array}{l}\text { os, Cambo } \\
\text { M }\end{array}$ & Thai, Lé & R Cambo & Thai, Viet & m, Cambo & Thai, Vie & am, Laos \\
\hline Dependent variable & $\begin{array}{l}\text { Outcome } \\
\text { linear } \\
\text { log Inc pc }\end{array}$ & $\begin{array}{c}\text { Treatment } \\
\text { probit } \\
\text { SPhone std }\end{array}$ & $\begin{array}{l}\text { Outcome } \\
\text { linear } \\
\text { log Inc pc }\end{array}$ & $\begin{array}{l}\text { Treatment } \\
\text { probit } \\
\text { SPhone std }\end{array}$ & $\begin{array}{l}\text { Outcome } \\
\text { linear } \\
\text { log Inc pc }\end{array}$ & $\begin{array}{l}\text { Treatment } \\
\text { probit } \\
\text { SPhone std }\end{array}$ & $\begin{array}{l}\text { Outcome } \\
\text { linear } \\
\text { log Inc pc }\end{array}$ & $\begin{array}{l}\text { Treatment } \\
\text { probit } \\
\text { SPhone std }\end{array}$ \\
\hline Household size & $\begin{array}{c}-0.022^{* * * *} \\
(4.6 \mathrm{e}-09)\end{array}$ & & $\begin{array}{c}-0.025^{\star * \star *} \\
(0)\end{array}$ & & $\begin{array}{c}-0.026^{* * * *} \\
(0)\end{array}$ & & $\begin{array}{c}-0.024^{* * * *} \\
(0)\end{array}$ & \\
\hline Education & $\begin{array}{l}0.0081^{* * * *} \\
(0.000024)\end{array}$ & & $\begin{array}{c}0.0073^{* * * *} \\
(0.0016)\end{array}$ & & $\begin{array}{c}0.0083^{* * * *} \\
(5.4 \mathrm{e}-06)\end{array}$ & & $\begin{array}{c}0.0080^{* * * *} \\
(3.3 \mathrm{e}-06)\end{array}$ & \\
\hline Ethnic majority & $\begin{array}{l}0.034^{*} \\
(0.061)\end{array}$ & & $\begin{array}{l}0.061^{* * * *} \\
(0.0047)\end{array}$ & & $\begin{array}{l}0.051^{* * * *} \\
(0.0045)\end{array}$ & & $\begin{array}{l}0.049^{* * * *} \\
(0.0025)\end{array}$ & \\
\hline Tangible assets & $\begin{array}{c}4.7 e-06^{* *} \\
(0.044)\end{array}$ & & $\begin{array}{c}2.8 \mathrm{e}-06^{* * *} \\
(0.0093)\end{array}$ & & $\begin{array}{c}3.3 e-06^{* * * *} \\
(0.0015)\end{array}$ & & $\begin{array}{c}3.1 \mathrm{e}-06^{* * * *} \\
(0.0020)\end{array}$ & \\
\hline Electricity grid & $\begin{array}{c}0.0071 \\
(0.81)\end{array}$ & & $\begin{array}{l}0.028 \\
(0.19)\end{array}$ & & $\begin{array}{l}0.018 \\
(0.53)\end{array}$ & & $\begin{array}{l}0.017 \\
(0.44)\end{array}$ & \\
\hline Mobile phone & $\begin{array}{c}0.071^{* \star \star *} \\
(0.000075)\end{array}$ & & $\begin{array}{l}0.046^{\star *} \\
(0.029)\end{array}$ & & $\begin{array}{l}0.082^{* \star \star \star} \\
(3.7 \mathrm{e}-06)\end{array}$ & & $\begin{array}{c}0.065^{\star \star \star *} \\
(0.000057)\end{array}$ & \\
\hline Smartphone standard & $\begin{array}{c}0.12 \\
(0.11)\end{array}$ & & $\begin{array}{c}0.25^{\star \star \star \star *} \\
(0.00042)\end{array}$ & & $\begin{array}{c}0.36^{\star \star \star \star} \\
(8.7 \mathrm{e}-09)\end{array}$ & & $\begin{array}{c}0.25^{\star \star \star \star} \\
(0.000010)\end{array}$ & \\
\hline Smartphone distr std & & $\begin{array}{c}4.94^{* * * *} \\
(1.3 e-06)\end{array}$ & & $\begin{array}{c}6.17^{* * * *} \\
(9.9 \mathrm{e}-09)\end{array}$ & & $\begin{array}{c}14.6^{* * * *} \\
(0)\end{array}$ & & $\begin{array}{c}6.96^{\star * * *} \\
(8.9 \mathrm{e}-10)\end{array}$ \\
\hline Consumption per capita & & $\begin{array}{c}0.00012^{\star * * *} \\
(0.00017)\end{array}$ & & $\begin{array}{c}0.000092^{* * * *} \\
(0.00015)\end{array}$ & & $\begin{array}{c}0.00012^{* * * *} \\
(0.00033)\end{array}$ & & $\begin{array}{c}0.00010^{* \star * *} \\
(6.8 \mathrm{e}-06)\end{array}$ \\
\hline Average age & & $\begin{array}{c}-0.0032 \\
(0.57)\end{array}$ & & $\begin{array}{l}-0.010^{*} \\
(0.060)\end{array}$ & & $\begin{array}{l}-0.010^{*} \\
(0.073)\end{array}$ & & $\begin{array}{c}-0.0090^{*} \\
(0.059)\end{array}$ \\
\hline Education & & $\begin{array}{c}0.017^{* * * *} \\
(0.0015)\end{array}$ & & $\begin{array}{l}0.016^{* *} \\
(0.012)\end{array}$ & & $\begin{array}{c}0.0090^{* *} \\
(0.031)\end{array}$ & & $\begin{array}{l}0.013^{* * * *} \\
(0.0013)\end{array}$ \\
\hline Off-farm employment & & $\begin{array}{l}0.080 \\
(0.10)\end{array}$ & & $\begin{array}{l}0.10^{\star *} \\
(0.016)\end{array}$ & & $\begin{array}{c}0.12^{\star * \star} \\
(0.0091)\end{array}$ & & $\begin{array}{c}0.10^{* * *} \\
(0.0067)\end{array}$ \\
\hline Self-employment & & $\begin{array}{c}0.16^{*} \\
(0.090)\end{array}$ & & $\begin{array}{c}0.16^{* *} \\
(0.035)\end{array}$ & & $\begin{array}{c}0.17^{* *} \\
(0.019)\end{array}$ & & $\begin{array}{c}0.15^{\star *} \\
(0.016)\end{array}$ \\
\hline Constant & $\begin{array}{c}8.64^{* * * *} \\
(0)\end{array}$ & $\begin{array}{c}-2.90^{* * * *} \\
(0)\end{array}$ & $\begin{array}{c}8.67^{\star \star \star \star *} \\
(0)\end{array}$ & $\begin{array}{c}-2.29^{\star * * *} \\
(0)\end{array}$ & $\begin{array}{c}8.65^{\star \star \star *} \\
(0)\end{array}$ & $\begin{array}{c}-2.83^{* * * *} \\
(0)\end{array}$ & $\begin{array}{c}8.65^{* \star * *} \\
(0)\end{array}$ & $\begin{array}{c}-2.72^{\star * \star *} \\
(0)\end{array}$ \\
\hline Province dummies ${ }^{\circ}$ & yes & no & yes & no & yes & no & yes & no \\
\hline Country dummies ${ }^{\circ}$ & no & no & no & no & no & no & no & no \\
\hline Number of observations & 3,170 & 3,170 & 3,161 & 3,161 & 4,568 & 4,568 & 4,572 & 4,572 \\
\hline
\end{tabular}

1 of 8 province dummies ommited due to collinearity; country dummies excluded due to lack of significance. 
Supplement F: Income effects (log annual per capita value) of smartphone ownership (binary) with mean income thresholds.

\begin{tabular}{|c|c|c|c|c|c|c|}
\hline $\begin{array}{l}\text { Column number } \\
\text { Estimation method }\end{array}$ & \multicolumn{2}{|c|}{$\begin{array}{c}1 \\
\text { ETR }\end{array}$} & \multicolumn{2}{|c|}{$\begin{array}{c}2 \\
\text { ETR }\end{array}$} & \multicolumn{2}{|c|}{$\begin{array}{c}3 \\
\text { ETR }\end{array}$} \\
\hline Dependent variable & $\begin{array}{c}\text { Outcome } \\
\text { linear } \\
\text { log Inc pc }\end{array}$ & $\begin{array}{c}\text { Treatment } \\
\text { probit } \\
\text { SPhone std }\end{array}$ & $\begin{array}{l}\text { Outcome } \\
\text { linear } \\
\log \text { Inc pc } \\
\end{array}$ & $\begin{array}{c}\text { Treatment } \\
\text { probit } \\
\text { SPhone std }\end{array}$ & $\begin{array}{l}\text { Outcome } \\
\text { linear } \\
\log \text { Inc pc } \\
\end{array}$ & $\begin{array}{c}\text { Treatment } \\
\text { probit } \\
\text { SPhone std }\end{array}$ \\
\hline Household size & $\begin{array}{c}-0.0049^{* *} \\
(0.031)\end{array}$ & & $\begin{array}{r}-0.014^{* * * *} \\
(5.7 e-09)\end{array}$ & & $\begin{array}{c}-0.0077^{* * * *} \\
(0.00045)\end{array}$ & \\
\hline Education & $\begin{array}{c}0.00085 \\
(0.29)\end{array}$ & & $\begin{array}{c}0.0059^{* * * *} \\
(2.4 \mathrm{e}-06)\end{array}$ & & $\begin{array}{c}0.0040^{* * * *} \\
(6.8 \mathrm{e}-06)\end{array}$ & \\
\hline Ethnic majority & $\begin{array}{l}0.015 \\
(0.23)\end{array}$ & & $\begin{array}{c}0.040^{* * * *} \\
(0.0029)\end{array}$ & & $\begin{array}{l}0.023^{*} \\
(0.063)\end{array}$ & \\
\hline Tangible assets & $\begin{array}{c}-3.2 e-08 \\
(0.97)\end{array}$ & & $\begin{array}{c}5.5 e-07 \\
(0.56)\end{array}$ & & $\begin{array}{c}-6.6 e-07 \\
(0.48)\end{array}$ & \\
\hline Electricity grid & $\begin{array}{r}-0.016 \\
(0.27)\end{array}$ & & $\begin{array}{c}0.0018 \\
(0.92)\end{array}$ & & $\begin{array}{c}-0.0031 \\
(0.84)\end{array}$ & \\
\hline Mobile phone & $\begin{array}{l}0.015 \\
(0.17)\end{array}$ & & $\begin{array}{l}0.053^{* * * *} \\
(9.4 \mathrm{e}-06)\end{array}$ & & $\begin{array}{l}0.021^{*} \\
(0.060)\end{array}$ & \\
\hline $\begin{array}{l}\text { Mean income } \\
\text { Mean + std dev income }\end{array}$ & $\begin{array}{c}0.54^{* * * *} \\
(0)\end{array}$ & & $\begin{array}{c}1.02^{* * * *} \\
(0)\end{array}$ & & & \\
\hline Mean sphone income & & & & & $\begin{array}{c}0.74^{* * * *} \\
(0)\end{array}$ & \\
\hline Smartphone standard & $\begin{array}{l}0.13^{* * * *} \\
(0.0018)\end{array}$ & & $\begin{array}{l}0.11^{* *} \\
(0.014)\end{array}$ & & $\begin{array}{l}0.11^{* * *} \\
(0.0052)\end{array}$ & \\
\hline Smartphone distr std & & $\begin{array}{c}8.03^{* * * *} \\
(0)\end{array}$ & & $\begin{array}{c}8.06^{* * * *} \\
(0)\end{array}$ & & $\begin{array}{c}8.10^{* * * *} \\
(0)\end{array}$ \\
\hline Consumption per capita & & $\begin{array}{c}0.000095^{\star * * *} \\
(9.4 \mathrm{e}-06)\end{array}$ & & $\begin{array}{c}0.000091^{* * * *} \\
(0.000027)\end{array}$ & & $\begin{array}{c}0.000092^{* * * *} \\
(0.000015)\end{array}$ \\
\hline Average age & & $\begin{array}{c}-0.0098^{* *} \\
(0.035)\end{array}$ & & $\begin{array}{c}-0.0095^{* *} \\
(0.041)\end{array}$ & & $\begin{array}{c}-0.0096^{* *} \\
(0.040)\end{array}$ \\
\hline Education & & $\begin{array}{l}0.015^{\star * * *} \\
(0.00048)\end{array}$ & & $\begin{array}{l}0.015^{\star * * *} \\
(0.00087)\end{array}$ & & $\begin{array}{l}0.015^{* * * *} \\
(0.00058)\end{array}$ \\
\hline Off-farm employment & & $\begin{array}{l}0.072^{* *} \\
(0.034)\end{array}$ & & $\begin{array}{l}0.074^{* *} \\
(0.040)\end{array}$ & & $\begin{array}{l}0.074^{* *} \\
(0.032)\end{array}$ \\
\hline Self-employment & & $\begin{array}{c}0.13^{* *} \\
(0.032)\end{array}$ & & $\begin{array}{l}0.13^{\star *} \\
(0.042)\end{array}$ & & $\begin{array}{l}0.13^{\star *} \\
(0.032)\end{array}$ \\
\hline Constant & $\begin{array}{l}8.56^{* * * *} \\
(0)\end{array}$ & $\begin{array}{c}-2.54^{* * * *} \\
(0)\end{array}$ & $\begin{array}{c}8.60^{* * * *} \\
(0)\end{array}$ & $\begin{array}{c}-2.53^{* * * *} \\
(0)\end{array}$ & $\begin{array}{c}8.59^{* * * *} \\
(0)\end{array}$ & $\begin{array}{c}-2.54^{* * * *} \\
(0)\end{array}$ \\
\hline Province dummies ${ }^{\circ}$ & yes & no & yes & no & yes & no \\
\hline Country dummies ${ }^{\circ}$ & no & yes & no & yes & no & yes \\
\hline Number of observations & 5,157 & 5,157 & 5,157 & 5,157 & 5,157 & 5,157 \\
\hline
\end{tabular}

Robust $p$-values in parentheses, significance levels: ${ }^{\star \star * *} p<0.005,{ }^{* * *} p<0.01,{ }^{* *} p<0.05,{ }^{*} p<0.1$.

$\circ 1$ of 8 province dummies and 1 of 4 country dummies ommited due to collinearity. 